\title{
Irrigation Market for Solar-Thermal Parabolic-Dish Systems
}

Hamid Habib-agahi

Sue Campbell Jones

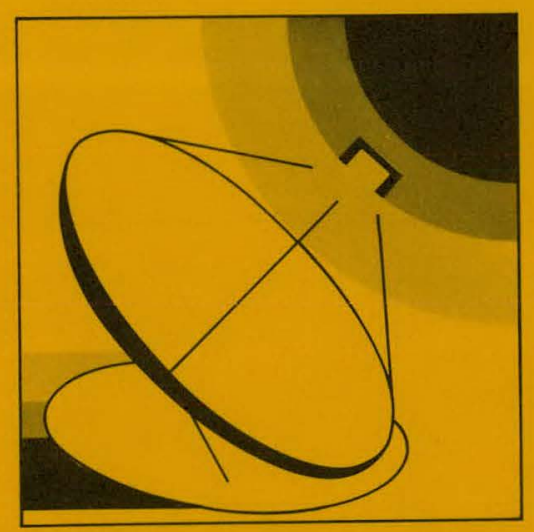

September 1,1981

Prepared for

U.S. Department of Energy

Through an agreement with

National Aeronautics and Space Administration

by

Jet Propulsion Laboratory

California Institute of Technology

Pasadena, California

(JPL PUBLICATION 81-85) 


\section{DISCLAIMER}

This report was prepared as an account of work sponsored by an agency of the United States Government. Neither the United States Government nor any agency Thereof, nor any of their employees, makes any warranty, express or implied, or assumes any legal liability or responsibility for the accuracy, completeness, or usefulness of any information, apparatus, product, or process disclosed, or represents that its use would not infringe privately owned rights. Reference herein to any specific commercial product, process, or service by trade name, trademark, manufacturer, or otherwise does not necessarily constitute or imply its endorsement, recommendation, or favoring by the United States Government or any agency thereof. The views and opinions of authors expressed herein do not necessarily state or reflect those of the United States Government or any agency thereof. 


\section{DISCLAIMER}

Portions of this document may be illegible in electronic image products. Images are produced from the best available original document. 


\title{
Irrigation Market for Solar-Thermal Parabolic-Dish Systems
}

\author{
Hamid Habib-agahi \\ Sue Campbell Jones
}

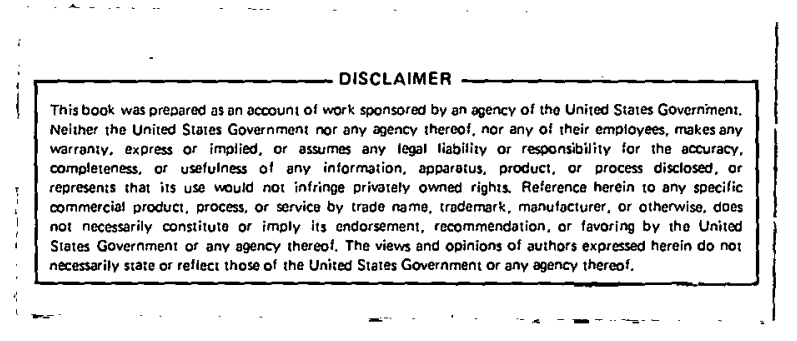

September 1, 1981

Prepared for

U.S. Department of Energy

Through an agreement with

National Aeronautics and Space Administration

by

Jet Propulsion Laboratory

California Institute of Technology

Pasadena, California

(JPL PUBLICATION 81-85) 
Prepared by the Jet Propulsion Laboratory, California Institute of Technology, for the U.S. Department of Energy through an agreement with the National Aeronautics and Space Administration.

The JPL Solar Thermal Power Systems Project is sponsored by the U.S. Department of Energy and forms a part of the Solar Thermal Prngram in deveinp lnw: cost solar thermal and electric power plants.

This report was prepared as an account of work sponsored by the United States Government. Neither the United States nor the United States Department of Energy, nor any of their employees, nor any of their contractors, subcontractors, or their employees, makes any warranty, express or implied, or assumes any legal liability or responsibility for the accuracy, completeness or usefulness of any information, apparatus, product or process disclosed, or represents that its use would not infringe privately owned rights. 
The potential size of the onfarm-pumped irrigation market for solar thermal parabolic dish systems in seven high-insolation states is estimated. The study is restricted to the displacement of three specific fuels: gasoline, diesel and natural gas.

A model was developed to estimate the optimal number of parabolic dish modules per farm based on the minimum cost mix of conventional and solar thermal energy required to meet irrigation needs. Results indicate that the near-term market for such systems depends not only on the type of crop and method of irrigation, but also on the optimal utilization of each added module, which in turn depends on the price of conventional fuel, real discount rate, marginal cost of the solar thermal power system, local insolation level and parabolic dish system efficiency.

The study concludes that the potential market size for onfarm-pumped irrigation applications ranges from 101,000 modules when a $14 \%$ real discount rate is assumed to 220,000 modules when the real discount rate drops to $8 \%$. Arizona, Kansas, Nebraska, New Mexico and Texas account for $98 \%$ of the total demand for this application, with the natural gas replacement market accounting for the largest segment $(71 \%)$ of the total market. 


\section{ACKNOWLEDGEMENT}

The authors thank E. S. Davis, W. Gates, R. O'Toole, J. L. Smith and K. Terasawa for their valuable review and contribution to the development of this document and $S$. Elrod for preparing and typing several versions of this paper. 
CONTENTS

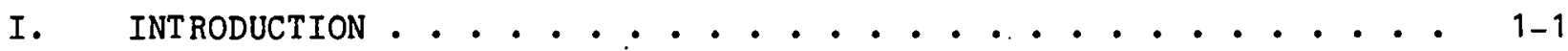

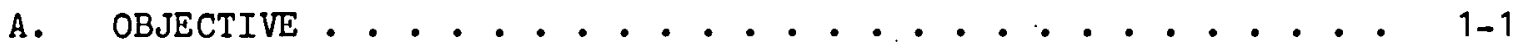

B. Potential ........................... 1-.

C. RESTRICTIONS ........................ 1-1

II. MAXIMUM MARKET SIZE ...................... 2-1

III. OPTIMAL MARKET SIZE ........................ 3-1

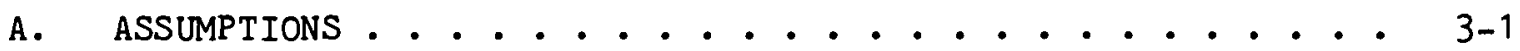

B. MODEL DEVELOPMENT .................. 3-1

C. DERIVATION OF TERMS ..................... 3-3

1. Insolation Evaluation ............... 3-3

2. Cost of Conventional Energy for Irrigation ...... 3-3

3. Solar Thermal System ............. 3-5

4. Solar Plant Utilization ............ 3-5

5. Market Size ................. 3-8

IV. SUMMARY AND CONCLUSIONS ...................... 4-1

REHERENCES . . . . . . . . . . . . . . . R-1

APPENDIXES

A. STATE IRRIGATION ENERGY DEMAND AND SUPFLY ....... A-1

B. Denivation of $k_{n}$ FOR various Regions ......... 


\section{Figures}

2-1. Composite Energy Demand and Solar Energy Supply

for a Kansas Farm . . . . . . . . . . . . . . . 2-1

A-1. Energy Demand and Supply Profiles for a Representative Farm in Kansas . . . . . . . . . . . . A-2

A-2. Energy Demand and Supply Profiles for a Representative Farm in California . . . . . . . . . . A-2

A-3. Energy Demand and Supply Profiles for a Representative Farm in New Mexico . . . . . . . . . A-3

A-4. Energy Demand and Supply Profiles for a Representative Farm in Nebraska ............. A-3

A-5. Energy Demand and Supply Profiles for a Representative Farm in Arizona .......... A-4

Tables

1-1. Acreage Irrigated with Onfarm-Pumped Water in 1977 . . . . 1-2

1-2. Price of Fuel by State in 1977 . . . . . . . . . . . 1-3

3-1. Average Annual Insolation by State . . . . . . . . 3-4

3-2. Conversion Factors . . . . . . . . . . . . 3-4

3-3. Energy Prices in 1990 . . . . . . . . . . . . . . . . .

3-4. Solar Plant Utilization Factor . . . . . . . . . 3-6

3-5. Optimal Utilization of Last Module . . . . . . . . . 3-8

3-6. Total Market for Onfarm-Pumped Irrigation Systems $(r=14 \%)$. 3-9

3-7. Total Market for Onfarm-Pumped Irrigation Systems $(r=8 \%)$. 3-10

4-1. Effective Utilization of the Optimally Sized PD System . . 4-2

B-1. Number of Modules Per Farm Per State . . . . . . . . . B-3

B-2. Arizona Irrigation Energy Demand and Supply . . . . . . B-5

B-3. California Irrigation Energy Demand and Supply . . . . . B-7

B-4. Kansas Irrigation Energy Demand and Supply . . . . . . . B-8

B-5: Nebraska Irrigation Energy Demand and Supply . . . . . . B-10

B-6. New Mexico Irrigation Energy Demand and Supply . . . . . B-11 
SECTION I

INT RODUCTION

\section{A. OBJECTIVE}

Increasing fuel prices and short supplies of conventional fuels during the past few years suggest that there may be applications for which solar thermal power systems will find a near-term market. One such application is providing the power necessary to run onfarm-pumped irrigation systems, particularly in western and southwestern regions which have relatively high levels of solar insolation. Onfarm-pumped irrigation systems are isolated, and frequently a grid connection is not available. The objective of this paper is to estimate the potential size of the onfarm-pumped irrigation market for parabolic dish (PD) systems. For this purpose, the analysis was confined to seven states with both high levels of insolation and high acreage of irrigated land.

\section{B. POTENTIAL}

In 1974, the U.S. agricultural sector consumed over two quadrilition British thermal units (Btu). More than $10 \%$ of this amount was used for irrigation, which provided over $20 \%$ of total U.S. crop production. Thus, irrigation is now and will continue to be a major consumer of energy. Ground water is the main source of onfarm-pumped irrigation water. In 1977, total acreage irrigated with onfarm-pumped water was over 40 million acres. Seven states with relatively high levels of insolation (California, Arizona, Colorado, Texas, New Mexico, Kansas, and Nebraska) accounted for $67 \%$ of the total land irrigated with onfarm-pumped water. Table $1=1$ summarizes the 1977 acreage irrigated with onfarm-pumped water in these states.

Electricity and natural gas supply $85 \%$ of the energy necessary to provide U.S. irrigation needs. Since 1974, the use of electricity, diesel, and natural gas to pump irrigation water has increased, while the use of gasoline has declined. Natural gas has been the least expensive fuel for pumping irrigation water, but it has been frequently unavailable. Electricity is generally the best alternative, but in some states utilities are operating at capacity and are not anxious to add to peak loads with more irrigation customers. Diesel fuel is the next best substitute, and its use for onfarmpumped irrigation doubied between 1974 and 1977 (Ref. 6). Table 1-2 shows the prices of different fuel and energy used for pumping irrigation water in 1977.

\section{RESTRI CTION3}

The following analysis is restricted in two ways: (1) by fuel type, to the replacement market for gasoline, diesel, and natural gas used for onfarmpumped irrigation water systems; and (2) by area, to seven states with characteristics which make the use of solar thermal parabolic dish systems attractive. The analysis is concentrated in this way for the following reasons: 
(1) Market Size. In 1977, over $1.3 \times 10^{14}$ Btu was generated to operate irrigation systems employing gasoline, diesel, and natural gas. In the near term, this is a reasonably-sized market to examine.

(2) Isolated Application. The modularity and "stand alone" features of PD modules make their use both feasible and attractive to isolated farms, especially where grid connections are unavailable and conventional fuels are both expensive and difficult to transport.

(3) Insolation. Many of the areas using irrigation systems in these states are aiso areas of relatively high insolation.

(4) Fuel Cost. A large percentage of onfarm-pumped irrigation system power is generated by gasoline, diesel, and natural gas. These are conventional fuels which solar will likely displace more rapidly than grid-oonneoted power.

Table 1-1. Acreage Irrigated with Onfarm-Pumped Water in 1977, by Type of Energy Source and State (1000 acres)

\begin{tabular}{lcccc}
\hline State & Electricity & Diesel & Gasoline & Natural Gas \\
\hline Kansas & 503 & 534 & - & 1911 \\
Nebraska & 1885 & 2262 & 62 & 1319 \\
Texas & 2204 & 107 & 93 & 6476 \\
Colorado & 1138 & 100 & 20 & 332 \\
New Mexico & 223 & 76 & 23 & 473 \\
California & 4757 & 9 & -- & - \\
Arizona & 648 & - & - & 291 \\
\hline
\end{tabular}

Source: Reference 6, pp. 21-22. 
Table 1-2. Price of Fuel by State in 1977

(1977 Dollars)

\begin{tabular}{lcccc}
\hline State & $\begin{array}{c}\text { Electricity } \\
\text { (per kWh) }\end{array}$ & $\begin{array}{c}\text { Diesel } \\
\text { (per Gallon) }\end{array}$ & $\begin{array}{c}\text { Gasoline } \\
\text { (per Gallon) }\end{array}$ & $\begin{array}{c}\text { Natural Gas } \\
\text { (per MCF) }\end{array}$ \\
\hline Kansas & 0.035 & 0.43 & -- & 0.80 \\
Nebraska & 0.045 & 0.45 & 0.51 & 1.20 \\
Texas & 0.030 & 0.45 & 0.55 & 1.30 \\
Colorado & 0.035 & 0.45 & 0.52 & 1.15 \\
New Mexico & 0.035 & $0.45^{\mathrm{a}}$ & $0.52^{\mathrm{a}}$ & 1.80 \\
California & 0.042 & 0.50 & -- & -- \\
Arizona & 0.021 & -- & -- & 1.50 \\
\hline
\end{tabular}

aThis is an estimate based on values available from neighboring states. Source: Reference 6, pp. 35-36. 
In order to estimate the size of the 1990 irrigation market for parabolic dish systems, the energy demanded for irrigation must be determined. The total supply of solar thermal energy will depend on the energy output and number of solar thermal systems installed to meet these energy demands. The market analysis must make some rational assumptions about the degree to which the total energy demanded for irrigation will be covered by the output of the solar thermal system.

Reference 1 estimated the energy demanded by several hypothetical, but representative, farms in Arizona, California, Kansas, Nebraska, and New Mexico. It also provided solar energy supply schedules based on theoretical systems sized to cover all peak demands. The solar system utilization, here referred to as $K$, is defined as the ratio of the total annual demand satisfied to the total amount of solar energy supplied.

To iliustrate, Figure 2-1 shows a composite energy demand and solar supply curve for a 260-acre Kansas farm. The energy demand is defined in megawatt hours per 15-day period. Demand includes residence, livestock operations and crop-drying requirements, as well as irrigation demands; since most of these additional demands occur at times when irrigation demands are lightest, they are included to increase the solar system utilization. The solar supply schedule is based on a system sized to cover all demand, taking into account regional insolation with variations throughout the year.

Appendix A provides further information about the supply and demand schedule of the representative farm for each state under study.

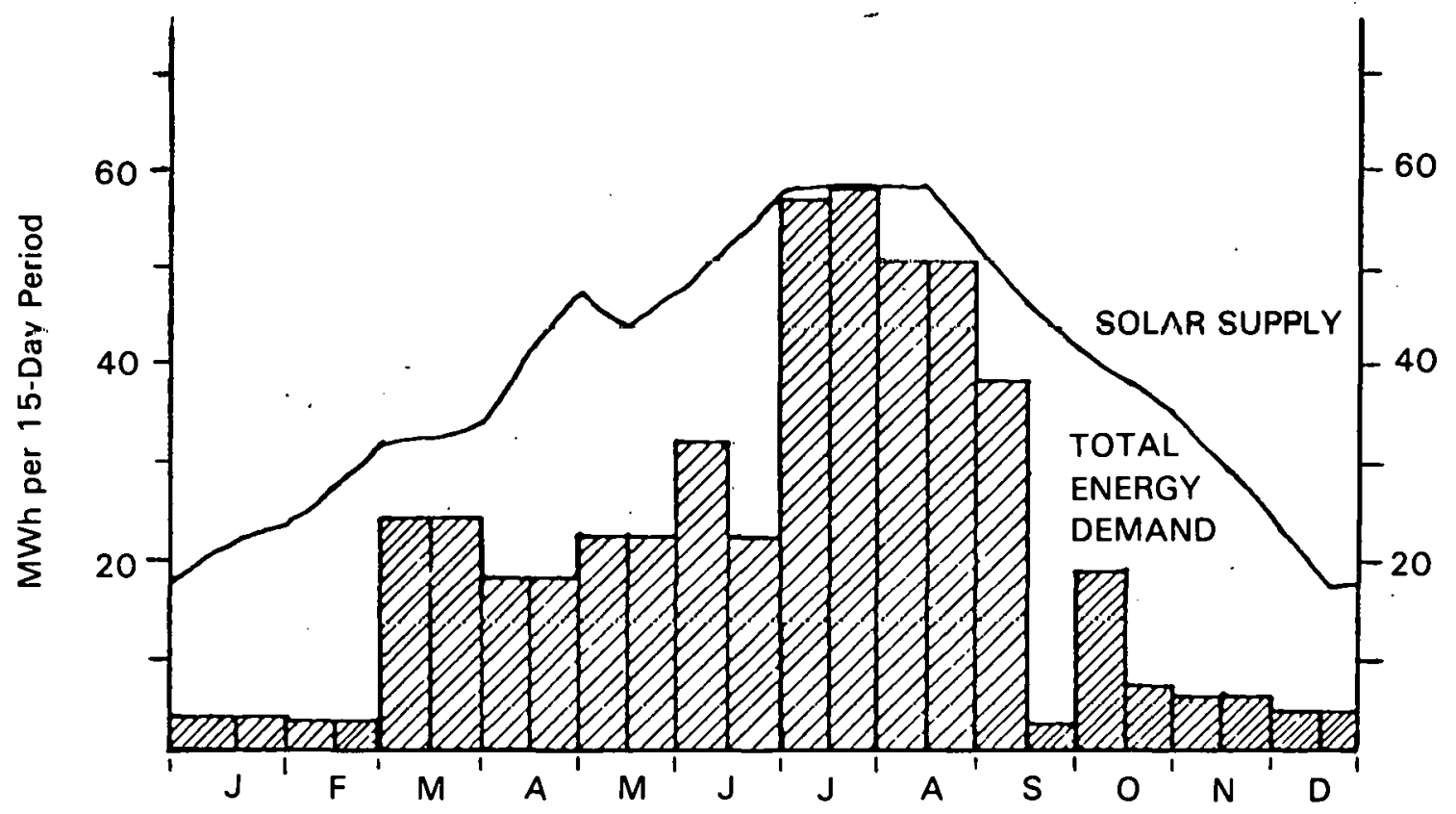

Figure 2-1. Composite Energy Demand and Solar. Energy Supply. for a Kansas Farm 
The irrigation market for parabolic dish systems could be estimated using this supply and demand information, with the number of modules calculated by the formula:

$$
X_{i j}=Z_{i j} /\left[A \cdot I_{j} \bullet \xi\right]
$$

where

$$
\begin{aligned}
& i \quad=\text { fuel type }=\text { diesel, gasoline, or natural gas } \\
& j \quad=\text { seven states studied } \\
& X_{i j}=\text { number of } P D \text { modules needed in the } j \text { th state to replace the } i \text { th } \\
& \text { fuel used for pumped irrigation } \\
& \begin{aligned}
z_{i j}= & \text { annual energy requirement for on-farm irrigation in state } j \\
& \text { using ith fuel, in } k w^{1}
\end{aligned} \\
& I_{j}=\text { annual average insolation in state } j \text { in } \mathrm{kWh} / \mathrm{m}^{2}-\mathrm{yr} \text {. (Table } \\
& \text { 3-1) } \\
& \xi \quad=\text { parabolic dish system efficlency }=20 \% \\
& A=\text { parabolic dish module size }=100 \mathrm{~m}^{2} / \text { module }
\end{aligned}
$$

Using data provided by the United States Department of Agriculture (Ref. 6) on the energy required for irrigation needs by state and by type of fuel, the total number of solar thermal parabolic dish modules that could potentially cover the demand can be estimated. Assuming conservatively that there is no significant change in the amount of land irrigated or in the type of onfarm-pumped irrigation since the Agriculture Department's 1977 data, the estimated number of modules needed to cover demand would be over 240,000 .

It should be noted that by using $I_{j}$, average annual insolation, and $Z_{i j}$, annual energy requirement, Equation (1) assumes that energy produced matches energy demanded. This would be a valid assumption if the solar thermal energy systems included a storage system that allowed energy produced in excess of demand, particularly during the off-seasons, to be used to meet peak demands for irrigation.

An alternative estimate can be made, based on the assumption that no auxiliary power or storage exists and that PD systems provide the total energy required. The utilization factor explained in Section III (Solar Plant Utilization) can be incorporated in Equation (1) to ensure an adequate number of parabolic dish modules to cover total demand, including peak periods. In this case, the number of solar thermal parabolic dish modules needed to cover the demand schedule in the seven states would be more than 500,000 modules. This implies the number of modules is sufficient to meet the peak requirements of the irrigation systems, but during the off-season when the demand for onfarm-pumped irrigation water is small, substantial energy would be wasted.

1Source: The total energy in million kWh was estimated, using the quantity of energy used for onfarm-pumped irrigation water given by Reference 6 , pp. 23-26, and conversion factors from Table 3-2. 
SECTION III

OPTIMAL MARKET SIZE

\section{A. ASSUMPTIONS}

In the preliminary analysis, initial market-size estimates were based on two assumptions. The first premise is that a system would be sized to meet all demand, assuming perfect storage. Alternatively, a system could be sized to completely cover peaks, in which case the demand would all be met; however, a large amount of excess supply would lead to a low system utilization. The optimal number of dishes for any given farm may not be that required to cover total demand and will vary depending not only on the type of crop and method of irrigation, but also on the marginal cost and availability of conventional energy and the marginal cost of solar thermal energy. Rather than meeting all energy requirements with PD systems, any specific farm should attempt to arrive at a cost-effective combination of solar and conventional energy. Because the value of solar thermal energy is directly related to. the irrigation demand satisfied by each module, the next step in estimating the optimalsized solar thermal system for each farm is to determine the utilization of each individual solar thermal module.

\section{B. MODEL DEVEL OPMENT}

The utilization factor $(K)$ given in Figures A-1 through A-5 shows the percent utilization of a solar system sized to cover peak demand and will vary substantially from state to state. As a parabolic dish system is installed, the power output of the first module will be highly utilized in satisfying demand. With the installation of each additional module, the average utilization of the system drops as supply more frequently exceeds demand, especially during off-peak periods. Therefore, the value of each additional PD module drops so that at some point, generally short of covering total demand, the farmer becomes indifferent toward supplying his energy needs with solar energy and supplying them with conventional energy. Thereafter, it would be more economical to use conventional energy. Thus, for each farm, there is an optimal number of modules which gives the most cost-effective combination of solar and conventional power for onfarm-pumped irrigation systems.

To determine what this optimal number would be, a mathematical model representing the cost of the total energy supplied was developed. The objective in finding the optimal number of modules is to minimize the total cost of energy to the user, the total being a combination of solar and conventional costs.

The total cost of energy for any given rarm currently using the ith fuel type would be:

$$
c^{i}=c_{s}+c_{c}^{i}
$$


where

$$
\begin{aligned}
& C_{s}=\text { cost of the solar thermal parabolic dish system } \\
& C_{c}^{i}=\text { cost of the conventional energy supplied by the ith fuel } \\
& \quad(i=\text { diesel, gasoline or natural gas }) \\
& C_{s}=N \cdot\left(\operatorname{CAP}+\sum_{t=1}^{T}\left(O M_{t}\right) /(1+r)^{t}\right)
\end{aligned}
$$

where

$$
\begin{aligned}
N & =\text { the number of parabolic dish modules } \\
C A P & =\text { capital coot of cach module } \\
O_{t} & =\text { operation and maintenance cost per module at time } t \\
r \quad & =\text { real discount rate } \\
T & =\text { system lifetime, } 30 \text { years } \\
C_{c}^{i} & =\sum_{t=1}^{T} P_{t}^{i}\left(\bar{Q}_{t}-\sum_{n=1}^{N}\left(A \cdot I \cdot \xi \cdot K_{n}\right)\right) /(1+r)^{t}
\end{aligned}
$$

which represents the demand for conventional energy as the difference between total energy demanded and that supplied by the solar system.

$$
\begin{aligned}
& \mathrm{P}_{t}^{i}=\text { price in year } t \text { of the ith fuel type } \\
& \bar{Q}_{t}=\text { total energy demanded in year } t \\
& A=\text { area per module, } 100 \mathrm{~m}^{2} \\
& I=\text { local insolation rate } \\
& \xi \quad=\text { system efficiency } \\
& K_{n}=\text { utilization of the nth module }
\end{aligned}
$$

The objective is to minimize the total cost with respect to $N$. Total cost can be written as:

$$
C^{i}=N \cdot\left(C A P+\sum_{t=1}^{T}\left(O M_{t}\right) /(1+r)^{t}\right)+\sum_{t=1}^{T} P_{t}^{i}\left(\bar{Q}_{t}-\sum_{n=1}^{N}\left(A \cdot I \cdot \xi \cdot K_{n}\right)\right) /(1+r)^{t}
$$

Optimality implies:

$$
\Delta C^{i}=C^{i}(N+1)-C^{i}(N) \geq 0 \text { and } C^{i}(N) \leq C^{i}(N-1)
$$


or

$$
\begin{aligned}
\Delta C^{i} & =(N+1) \cdot\left(C A P+\sum_{t=1}^{T} O M_{t} /(1+r)^{t}\right)+\sum_{t=1}^{T} P_{t}^{i}\left(\bar{Q}_{t}-\sum_{n=1}^{N+1} A \cdot I \cdot \xi^{+1} \cdot K_{n}\right) /(1+r)^{t} \\
& -N \cdot\left(C A P+\sum_{t=1}^{T} O M_{t} /(1+r)^{t}\right)-\sum_{t=1}^{T} P_{t}^{i}\left(\bar{Q}_{t}-\sum_{n=1}^{N} A \cdot I \cdot \xi_{*} \cdot K_{n}\right) /(1+r)^{t}
\end{aligned}
$$

Monotonicity of $\mathrm{K}_{\mathrm{n}}$ guarantees the existence of a solution, hence

$$
\Delta C^{i}=C A P+\sum_{t=1}^{T} O M_{t} /(1+r)^{t}-\sum_{t=1}^{T}\left(P_{t}^{i} \cdot A \cdot I \cdot \xi \cdot K_{N+1} /(1+r)^{t}\right) \geq 0
$$

Equation (1) can be solved for $\mathrm{K}_{\mathrm{N}}$ and written,

$$
K_{N} \geq K_{\hat{N}}=\left(C A P+\sum_{t=1}^{T} O M_{t} /(1+r)^{t}\right) /\left((A \cdot I \cdot \xi) \sum_{t=1}^{T} P_{t}^{i} /(1+r)^{t}\right) \geq K_{N+1}
$$

This solution, $\mathrm{K}_{\hat{N}}$, gives the optimal utilization of the $\mathrm{Nth}$ module, where $\hat{\mathrm{N}}$ represents the last module added.

This mathematical model, which will allow for the estimation of the optimal size of a farm's solar system, necessitates a numerical definition of each term of the model.

\section{DERIVATION OF TERMS}

\section{Insolation Evaluation}

Average annual direct insolation data (I) for the seven states was obtained from Table 2 of Reference 3. The sites selected to represent the states were chosen based on the closest sites to SOLMET data stations in that region. It should be noted that in using average annual insolation data for the sites selected, it was assumed that at these locations, the data approximate the insolation and temperature characteristic of the state as a whole. Table 3-1 presents the insolation data used for each state.

\section{Cost of Conventional Energy for Irrigation}

Projected estimates for 1990 fuel costs for onfarm-pumped irrigation water to farmers (Table 3-2) were obtained from Reference 2. The following conversion factors were used to convert all fuel cost units for various types of resources into a common energy measure, $\$ / \mathrm{kWh}$.

Fuel prices were derived by simple multiplication from 1990 energy prices (in 1980 dollars). Table 3-3 gives the prices used as well as the projected growth rates and the energy conversion factors in Table 3-2. 
Table 3-1. Average Annual Insolation by State

\begin{tabular}{lll}
\hline State & Observation Location & Insolation $\left(\mathrm{kWh} / \mathrm{m}^{2}-\mathrm{yr}\right)^{\mathrm{a}}$ \\
\hline Arizona & Phoenix & 2526 \\
California & Fresno & 2237 \\
Colorado & Great Falls, Montanab & 1661 \\
Kansas & Dodge City \\
Nebraska & North Omaha & 2106 \\
New Mexicn & Alhuquerque. & 1632 \\
Texas & Fort Worth & 2602 \\
\hline
\end{tabular}

aSOLMET long-term direct normal average (Ref. 3).

$\mathrm{b}_{\text {This insolation data is used for the state of Colorado, since no SOLMET }}$ station is available in Colorado.

Table 3-2. Conversion Faclors

Fuel

Diesel

Gasoline

Natural Gas

Heat Ratea

Gasoline Engine

Diesel Engine

Gas Turbine

Coal Fired Steam

\section{Conversion}

1 Gallon $=138,690 \mathrm{Btu}$

1 Gallon $=125,000 \mathrm{Btu}$

1 Cubic Foot $=1000 \mathrm{Btu}$

aBased on experts' estimates for typical engines used for water pumping. Source: Reference 5, p. 3-126. 
Table 3-3. Energy Prices in 1990

$(\$ 1980)$

\begin{tabular}{lccc}
\hline Fuel & \$/Milion Btu & \$/kWh & $\begin{array}{c}\text { Growth Rate, } \\
(1990-2010)\end{array}$ \\
\hline Gasoline & $\$ 13.47$ & $\$ 0.188$ & 2.8 \\
Diesel & 9.00 & 0.135 & 2.5 \\
Natural Gas & 6.02 & 0.120 & 3.2 \\
\hline
\end{tabular}

3. Solar Thermal System Efficiency

In order to transform solar energy to electrical power, we used a solar thermal power system consisting of a series of point-focusing parabolic dishes with the following characteristics:

(1) concentrator efficiency $=90 \%$

(2) receiver efficiency $=82 \%$

(3) power conversion efficiency $=25-35 \%$

(4) all other Iosses including transportation $=4 \%$

(5) collector size $=100 \mathrm{~m}^{2}$

(6) total system efficiency $=20 \%$

(7) production at 5,000-25,000 units/yr.

Thus, throughout this paper, the solar thermal system efficiency $(\xi)$ of $20 \%$ is assumed for all solar plants (Ref. 4).

\section{Solar Plant Utilization}

A solar thermal plant utilization factor $(K)$ is defined as the ratio of the energy demand which is met by the solar thermal system to the total energy available from the solar system. Two identical solar systems can have vastly differing utilization factors depending both on the demand schedules and on differences in insolation levels, which create different power outputo. It should be kepl in mind that a high utilization factor does not necessarily mean that all demand is being met but does indicate the percent of supply being utilized.

In this analysis, one farm for each state was selected as representative of that state's irrigation demand patterns and solar supply characteristics. Each farm's solar plant utilization factor olosely resembles the average utilization factor obtained by Reference 1 . The value of $\mathrm{K}$ varies from $64.6 \%$ 
in Arizona to $36.9 \%$ in California. Crop-drying and livestock operations have relatively low summer energy requirements and can increase solar plant utilization factors by running their power requirements off the solar plant during times of under-utilization by the irrigation systems. Thus, in this study, the demand schedule includes energy required for irrigation, residence, and crop drying. The data obtained by Reference 1 indicates that in all the seven states except Nebraska, the energy requirement for farm residence and crop drying is very small relative to energy demanded for irrigation.

It should be noted that important factors such as farm size, type of irrigation, and cropping pattern have been considered in determining the energy demand schedule for irrigation. Further details are given in Appendix A, and Figures A-1 to A-5 show the energy supply and demand schedules. Table 3-4 provides the solar utiiization factor $(K)$ for a solar thermal system designed to satisfy peak power demand in Kansas, Nebraska, Texas, Colorado, New Mexico, California and Arizona.

a. Marginal Solar Plant Utilization. Table 3-4 gives an average utilization factor (K) for a system large enough to require no auxiliary power snurce. However, in practical terms, most consumers would attempt to achieve a cost-effective balance of solar and conventional energy sources by oplimlizing the utilization of the Nth module. The marginal utilization is the ratio of the additional demand covered by the nth module to the additional power supplied. As each module is added to a system, this ratio will drop. This is due to the variations of supply and demand over time, so that as a system gets larger and larger, the supply will more frequently exceed demand.

Table 3-4. Solar Plant Utilization Factor (K)

Location

Kansas

Nebraska

Texas $^{a}$

Coloradoa

New Mexico

California

Arizona
K (\$)
55.1

43.9

45.0

42.0

42.4

36.9

64.6

a These are estimates based on values obtained from neighboring states. Source: Reference 1. 
For example, on the representative farm in the state of Kansas, the first three modules instalied are utilized $100 \%$ of the time. The fourth module added to the system, however, is utilized only $97 \%$ of the time, while by the time the tenth module is added, the marginal utilization is $62 \%$. This means that while the tenth module generates as much energy as each of the first nine, total demand met will only be increased by $62 \%$ of the amount generated. Thus, the marginal solar plant utilization $\left(K_{n}\right)$ for Kansas is 0.62 , when $\mathrm{n}=10$.

Appendix $B$ details the derivation of each $K_{n}$ for each farm in various regions, and contains complete tables of the results, Tables B-2 to B-6.

b. Optimal Solar Plant Utilization. The preceeding portions of Section 3 defined a mathematical model for determining the optimal utilization of the Nth module, expressed in Equation (2) as:

$$
K_{\hat{N}}=\left(C A P+\sum_{t=1}^{T} O M_{t} /(1+r)^{t}\right) /\left((A \cdot I \cdot \xi) \sum_{t=1}^{T} P_{t}^{i} /(1+r)^{t}\right)
$$

and the derivation of the variables needed to make the calculations. With the following assumptions, optimal solar plant utilization $\left(\mathrm{K}_{\hat{N}}\right)$ can be calculated for each state and fuel type.

(1) The first year of operation is 1990.

(2) All costs are in 1980 dollars.

(3) Capital cost per module is $\$ 27,000$, the 1990 cost goal, established by the Cost Goal Committee (Ref. 4).

(4) Minimum production level of 5000 /modules, necessary to meet cost goals.

(5) Annual operation and maintenance cost is $2 \%$ of capital cost.

(6) The real operation and maintenance (O\&M) escalation rate is $1 \%$ annually.

(7) Real discount rate is $14 \%$.

(8) Insolation is as presented in Section III.

(8) Dish size is $100 \mathrm{~m}^{2}$.

(10) System efficiency is $20 \%$, as presented in Section III.

(11) System lifetime is 30 years.

(12) The total energy supply and demand patterns per state are the same as that represented by the "typical" farms of Figures $A-1$ to $A-5$, increased multiplicatively. 
(13) Average annual real price escalation rates for conventional fuels for the period 1990 to 2020 are derived from Reference 2 and continuation of past trend:

$\begin{array}{ll}\text { Gasoline } & 2.5 \% \\ \text { Diesel } & 2.8 \% \\ \text { Natural Gas } & 3.2 \%\end{array}$

Using Equation (2), the optimal marginal utilization of the last module added, $\mathrm{K}_{\hat{N}}$, which would minimize the total cost of energy, was obtained for each state and fuel type. The results are given in Table 3-5.

\section{Market Size}

The marginal utilization of each module, $\mathrm{K}_{\mathrm{n}}$, was cxplained in Subsection a (Marginal Solar Plant Utilization), and is given in the tables in Appendix 2. Thus, when the optimal utilization of the lasl midule, $\mathrm{K}_{\hat{N}}$, io obtained from Subsection b (Optimal Solar Plant Utilization), the cost minimizing number of modules, $\hat{N}$, can be read from the tables. This gives the number

Table 3-5. Optimal Utilization of Last Module $(r=14 \%)$

\begin{tabular}{lll}
\hline State & Fuel Displaced & $\mathrm{K}_{\hat{\mathrm{N}}}$ \\
\hline New Mexico & Casoline & 0.37 \\
New Mexico & Diesel & 0.50 \\
California & Diesel & 0.59 \\
Kansas & Diesel & 0.62 \\
Texas & Gasoline & 0.57 \\
Colorado & Gasoline & 0.58 \\
Texas & Diesel & 0.77 \\
Nebraska & Gasoline & 0.59 \\
Arizona & Natural Gas & 0.63 \\
New Mexico & Natural Gas & 0.55 \\
Colorado & Diesel & 0.79 \\
Nebraska & Diesel & 0.80 \\
Texas & Natural Gas & 0.84 \\
Kansas & Natural Gas & 0.68 \\
Colorado & Natural Gas & 0.86 \\
Nebraska & Natural Gas & 0.87 \\
\hline
\end{tabular}


of modules on the optimally-sized representative farm. Returning to the example of Kansas, $\mathrm{K}_{\hat{\mathrm{N}}}$ for diesel is $62 \%$. Table $\mathrm{B}-4$ shows that $\hat{\mathrm{N}}$ associated with 0.62 is 10. Thus, on the representative farm in Kansas, if diesel fuel is used to run an onfarm-pumped irrigation system, an optimally sized PD system would be ten modules.

Using the data received from the Department of Agriculture (Ref. 6), giving the current energy usage in each of the seven states for irrigation by each fuel type, an equivalent number of farms irrigated by each fuel can be calculated. The potential solar market then becomes the product of the number of farms times the number of modules per farm. The results are given in Table 3-6, and a detailed explanation is given in Appendix B. For Kansas, the energy supplied by diesel fuel to power onfarm-pumped irrigation is $380 \times 10^{6} \mathrm{kWh}$. The annual energy used by the representative farm is $511,700 \mathrm{kWh}$. Therefore, there are 743 equivalent farms, each with a potential to install an optimally sized PD system of ten modules for a total potential market of 7430 modules.

The total potential market for parabolic dish systems to supply power for onfarm-pumped irrigation systems in these seven states is over 101,000 modules. As can be seen, five of the states provide most of the demand, with the other two accounting for less than $2 \%$ of the total. The natural gas replacement market accounts for the largest segment $(71 \%)$ of the total market.

For a capital intensive technology such as parabolic dish systems, the results are sensitive to the real discount rate chosen. The analysis was performed with $14 \%$ as the real discount rate. If, however, we look at sizing a farm system for optimum cost effectiveness using a real discount rate of $8 \%$, the total market size estimate will increase to over 220,000 modules from 101,000 with a $14 \%$ discount rate. Table 3-7 gives the re-estimated market size by state and fuel type.

Table 3-6. Total Market for Onfarm-Pumped Irrigation Systems $(r=14 \%)$

\begin{tabular}{lccrr}
\hline & \multicolumn{3}{c}{ Number of Modules to Replace } & \\
\cline { 2 - 5 } State & Gasoline & Diesel & Natural Gas & Total \\
\hline New Mexico & 1,044 & 2,568 & 13,520 & 17,132 \\
California & -- & 189 & -- & 189 \\
Texas & 1,365 & 344 & 9,695 & 11,404 \\
Kansas & -- & 7,430 & 21,114 & 28,544 \\
Colorado & 56 & 70 & 692 & 818 \\
Arizona & - & -- & 18,974 & 18,974 \\
Nebraska & 1,040 & 15,640 & 7,722 & 24,402 \\
\hline
\end{tabular}


Table 3-7. Total Market for Onfarm-Pumped Irrigation Systems

$(r=8 \%)$

\begin{tabular}{lcccc}
\hline & \multicolumn{2}{c}{ Number of Modules to Replace } & \\
\cline { 2 - 4 } State & Gasoline & Diesel & Natural Gas & Total \\
\hline New Mexico & 1,160 & 2,889 & 15,210 & 19,259 \\
California & - & 252 & - & 252 \\
Texas & 1,755 & 1,376 & 77,560 & 80,691 \\
Kansas & - & 8,916 & 28,152 & 37,068 \\
Colorado & 72 & 280 & 5,536 & 5,888 \\
Arlizona & - & - & 21,112 & 21,112 \\
Nebraska & 2,080 & 39,100 & 15,444 & 56,624 \\
\hline
\end{tabular}


SECTION IV

SUMMARY AND CONCLUSIONS

The characteristics of onfarm-pumped irrigation systems fit the profile of the near-term solar thermal parabolic dish market: While in some areas of the country, 1rrigation systems are grid connected, a portion of the market can be identified in which the irrigation systems are isolated, currently powered with increasingly expensive fuels and located in areas with available land for modules. In estimating the near-term potentials for PD markets, it is important to focus on specific applications in which success is most probable.

The foregoing analysis estimates the near-term market size as ranging between 101,000 and 220,000 modules. The market size estimates vary with the discount rate chosen, with the number of modules increasing as the rate drops. The 101,000-module and 220,000-module estimates are based on real discount rates of $14 \%$ and $8 \%$, respectively. This market analysis is restricted to the seven states identified as having both high levels of insolation and high acreage of irrigation land. It is also restricted to displacement of three specific fuels, diesel, gasoline and natural gas, with relatively rapidly escalating prices. While this may lead to some underestimation due to the characteristics of the areas analyzed, the largest proportion of the market has been captured. One additional comment on the market in general is that a consideration of market estimates of parabolic dish modules is the availability of land. Since the number of modules per farm in this analysis averages 10 or fewer, the required land should not be a constraint to installation decisions on a farm.

The estimates take into account decisions about cost effective utilization of the solar thermal system to define the appropriate mix of solar and conventional power. Of course, the optimal mix of solar and conventional power on any farm will be influenced by the price of conventional fuels and anticipated relative escalation rates.

The model developed in this paper identifies the optimal utilization of the last module added to the system, and based on that calculation, defines the size of the optimal system. By finding the marginal utilization of each module added to a system, the effective utilization of the optimally sized system can be calculated. Relatively high effective utilization factors indicate high utilization of each module, with little wasted solar energy. The high effective utilization rates of the systems displacing natural gas, as shown in Table 4-1, indicate that this market will be relatively unaffected by minor fluctuations in insolation levels. This stability is significant to the analysis, as over $73 \%$ of the PD market is for displacement of natural gas.

In addition to limiting the scope of the analysis to seven states and three fuels, several assumptions were made. Data on the current size of the irrigation market was from 1977, and no significant changes were assumed for 1990. In cases in which no data existed, neighboring states were used as proxies. In all cases, attempts were made to keep estimates on the conservative side, if possible. Two major assumptions were: (1) that a single observation location adequately represented the insolation data for a state as 
a whole, and (2) that the representative farm adequately represented the supply and demand profiles of the state as a whole. Finally, there was no consideration of competition for the same market from any other renewable or alternative source.

The calculation of the optimal utilization rate of the last module added is highly sensitive to the real discount rate chosen. This suggests an area for future investigation.

Table 4-1. Effective Utilization of the Optimally Sized PD System $(r=14 \%)$

\begin{tabular}{lll}
\hline State & Replaced Fuel & Effective Utilization \\
\hline New Mexico & Gasoline & 0.66 \\
California & Diesel & 0.68 \\
New Mexico & Diesel & 0.69 \\
Texas & Gasoline & 0.72 \\
Colorado & Gasoline & 0.72 \\
New Mexico & Natural Gas & 0.69 \\
Nebraska & Gasoline & 0.75 \\
Texas & Diesel & 0.80 \\
Arizona & Natural Gas & 0.84 \\
Colorado & Diesel & 0.80 \\
Colorado & Natural Gas & 0.88 \\
Kaisas & Diesel & 0.86 \\
Nebraska & Diesel & 0.89 \\
Texas & Natural Gas & 0.88 \\
Kansas: & Natural Gas & 0.88 \\
Nebraska & Natural Gas & 0.89 \\
\hline
\end{tabular}




\section{REFERENCES}

1. Agricultural Practices Which Could Enhance Solar Powered Irrigation Plant Utility: Energy Demand and Plant Utilization; Department of Soils, Water and Engineering and Agricultural Economics, University of Arizona, Tucson, Arizona, 1978.

2. Energy Review, Data Resources, Inc., Lexington, Massachusetts, Spring 1981.

3. Habib-agahi, H., and Smith, J. H., Regional Analysis of Solar Thermal Electric and Conventional Power Plants, JPL Internal Document 5105-69, January 1981.

4. Annual Technical Report, Fiscal Year 1980, DOE Report, DOE/JPL 1060-45, JPL Publication 81-39, May 15, 1981.

5. Solar Thermal Plant Impact Analysis Requirements Definition Study, Science Applications, Inc., Summary Report for Tasks 1, 2 and 3; prepared under JPL Contract No. 955238, September 7, 1979.

6. Slogget, Gordon, Energy and U.S. Agriculture: Irrigation Pumping 19741977 , U.S. Department of Agriculture, September 1979 . 


\author{
APPENDIX A \\ STATE IRRIGATION ENERGY DEMAND AND SUPPLY
}

SOLAR ENERGY PROFILES

The following descriptive information concerning the irrigation energy demand and solar supply profiles for representative farms, as well as the graphs, was obtained from Reference 1.

In Kansas, cropping and livestock operations are common. Crop drying represents a substantial autumn energy requirement for the farms growing grain, while heating requirements for the residence and for swine operations are greater in the winter than in the summer. In the evaluation of energy demand schedules, the energy requirements for crop drying, residential use, animal operations and irrigation were considered. The solar utilization factor in this state is estimated to be $55.1 \%$, with the peak demand occurring in the month of July (Figure A-1).

In California, farms are quite specialized in growing grapes, almonds, cotton, alfalfa and wheat. In this case, a solar utilization of $36.9 \%$ is expected. The residential demand is very small and peak demand for irrigation occurs during the summer season (Figure A-2).

In New Mexico, besides demand for irrigation, the energy requirements for residential use and crop drying were considered even though the demand is very small. The peak demand occurs in the month of May and the solar utilization factor is $42.4 \%$ (Figure $\mathrm{A}-3$ ).

In Nebraska, farms growing corn, with crop drying, cattle feeding, residence, and swine operations were considered. The peak demand occurs in the month of August and the solar utilization factor is $43.9 \%$ (Figure A-4).

In Arizona, farms growing alfalfa and wheat were considered. The total energy demanded for irrigation in this case spreads over 9 months of the year with energy peak demand in the month of June. The solar utilization factor for this state is $64.6 \%$, which is relatively high with respect to other states (Figure $A-5$ ).

For further information about the solar plant utilization factor, see Reference 1. 


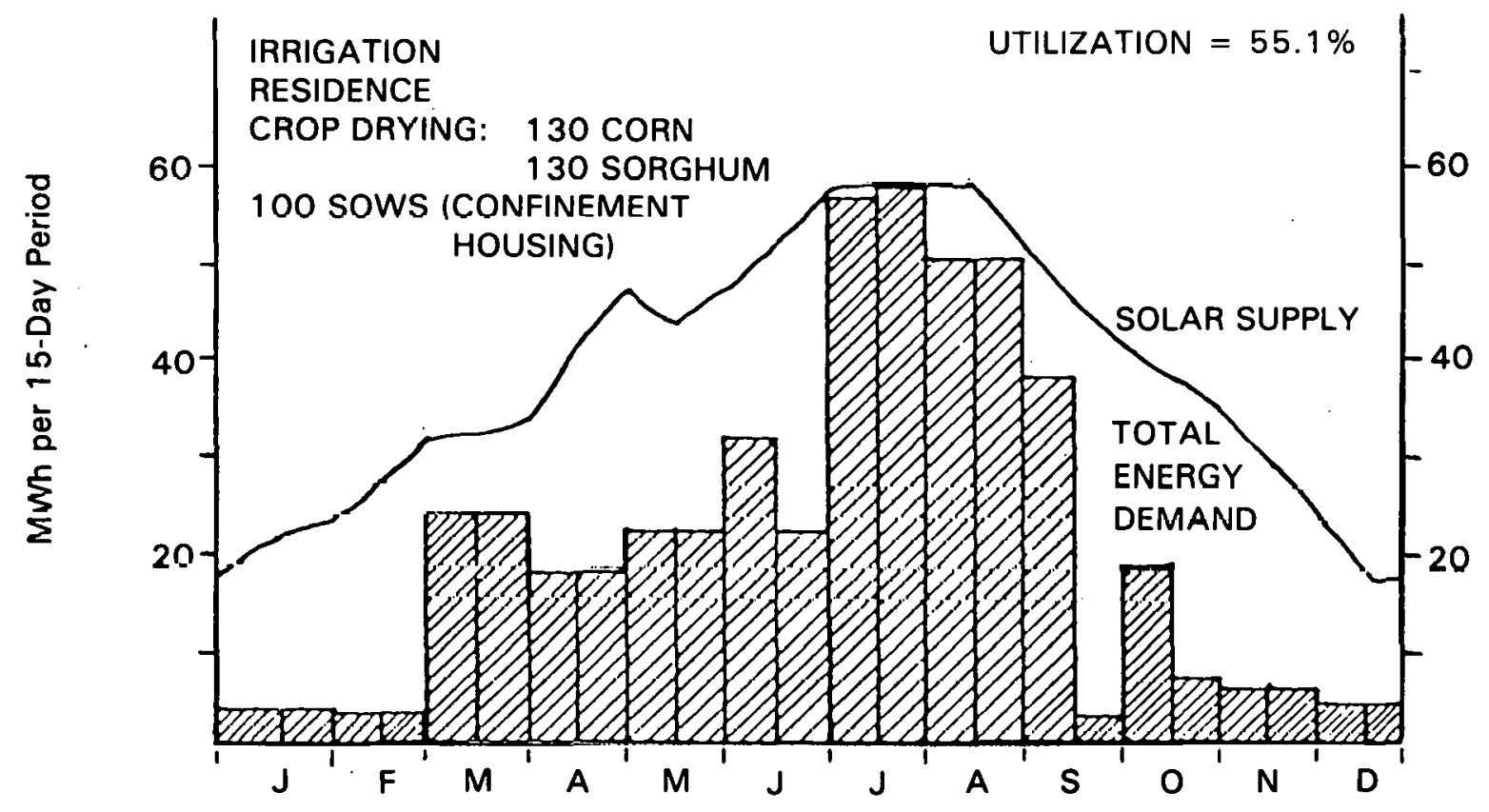

Figure A-1. Composite Energy Demand and Solar Energy Supply Curves for a 260-Acre Kansas Farm. Includes Irrigation, Residence, Crop Drying and Animal Production

\section{CALIFORNIA - FARM}

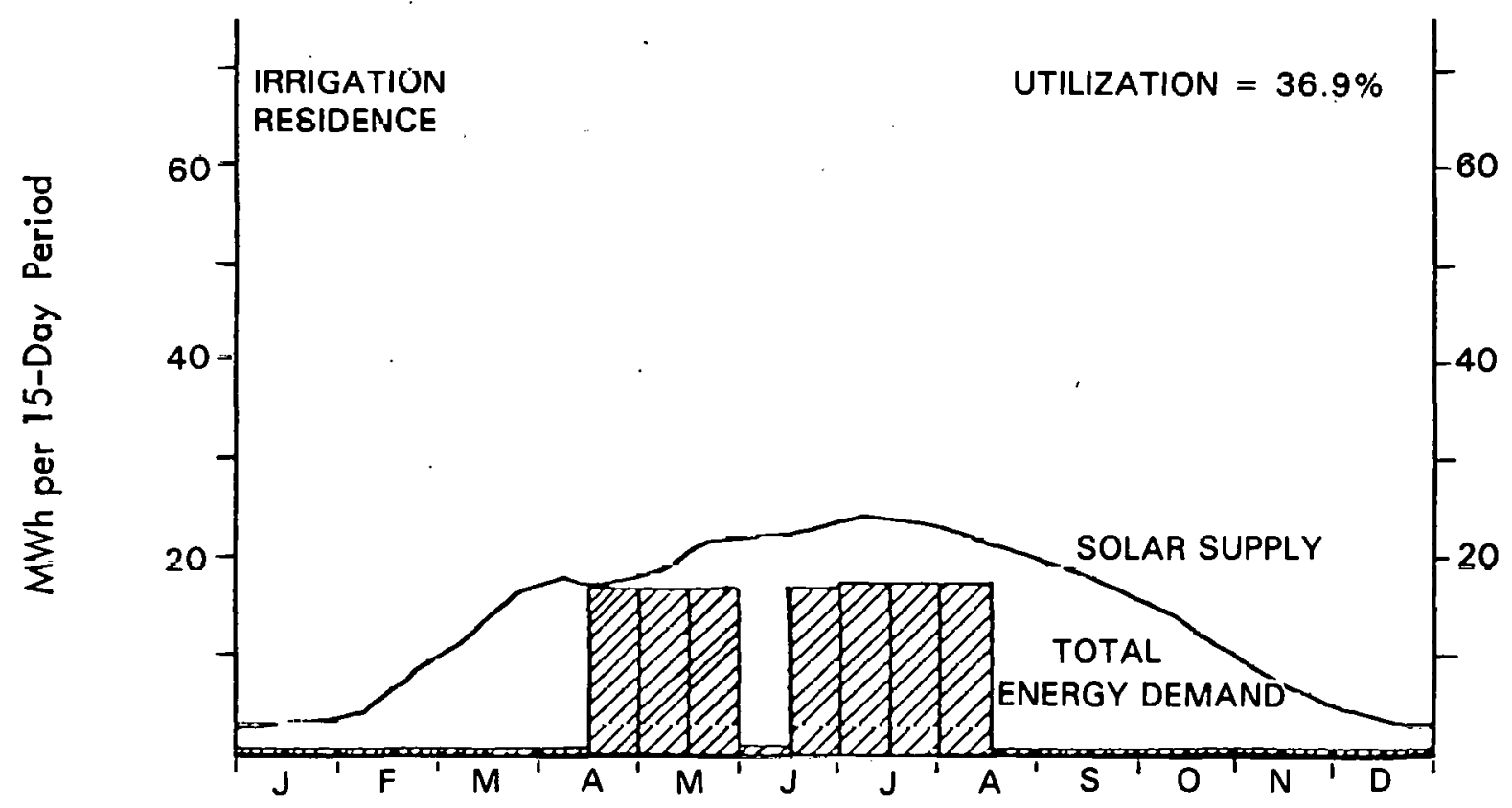

Figure A-2. Composite Energy Demand and Solar Energy Supply Curves for a 150-Acre Upper San Joaquin Valley, California, Farm, Includes Irrigation and Residence 
NEW MEXICO - FARM

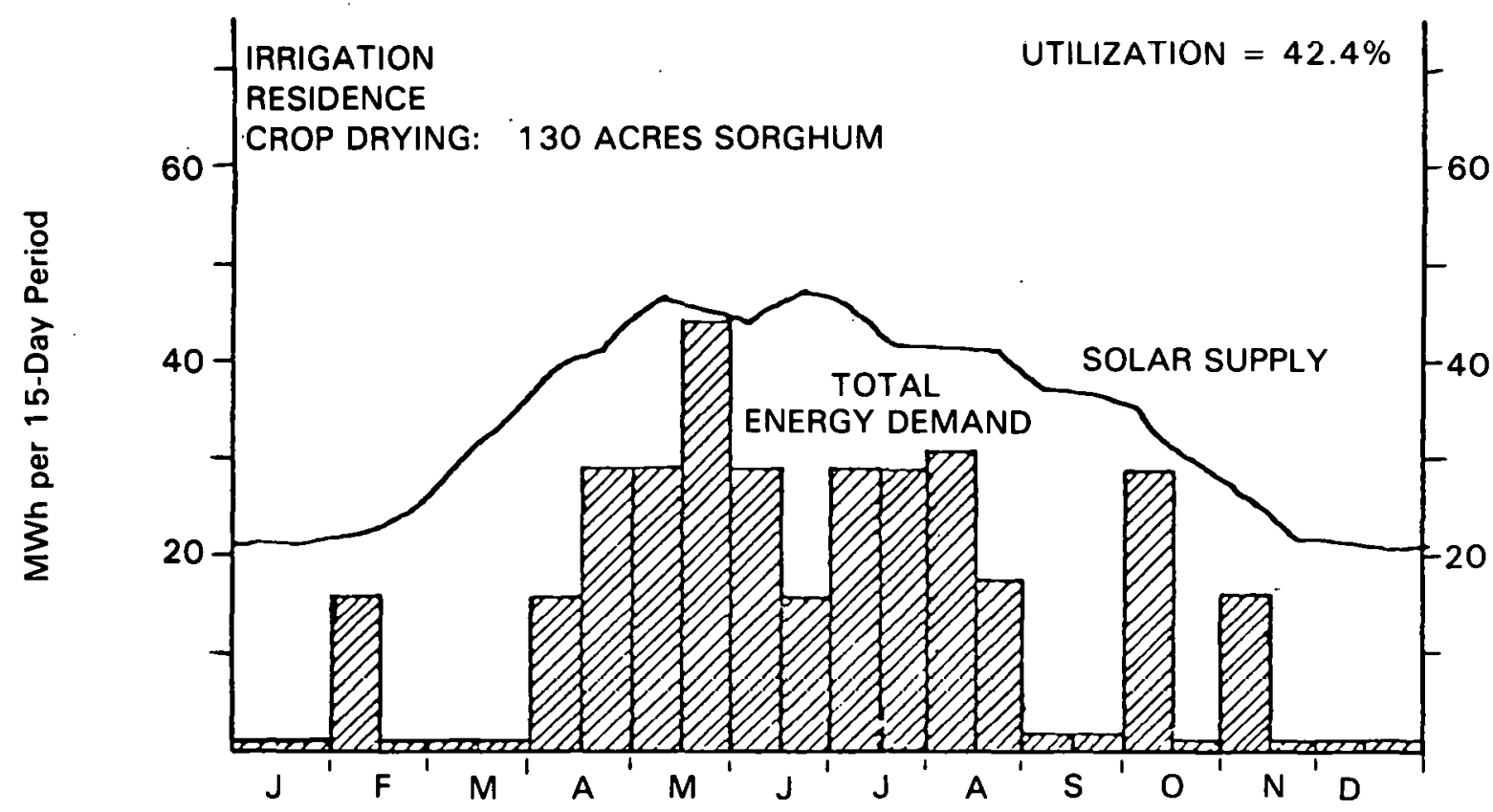

Figure A-3. Composite Energy Demand and Solar Energy Supply Curves for a 390-Acre Northern New Mexico Farm. Includes. Irrigation, Residence, and Crop Drying NEBRASKA - FARM

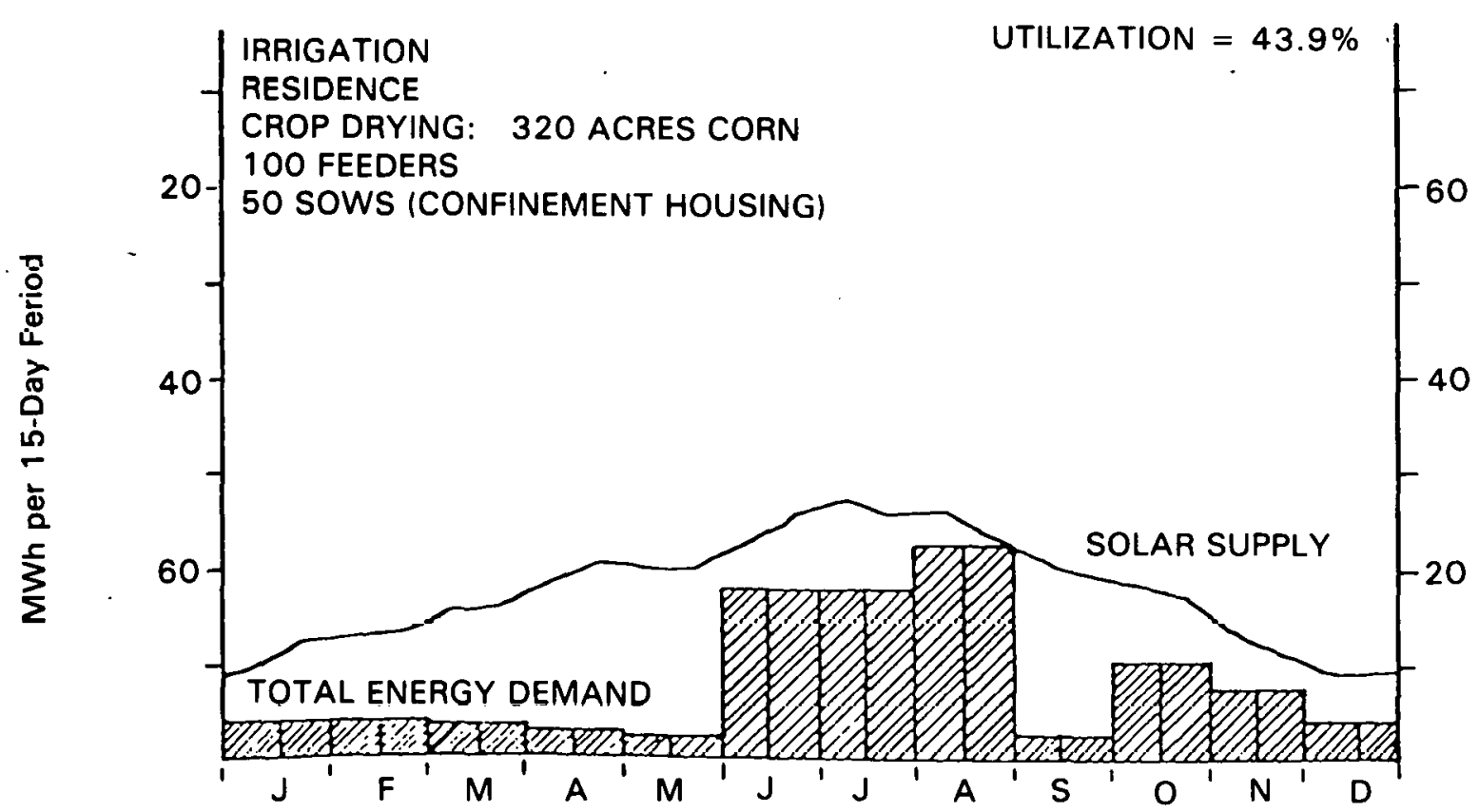

Figure A-4. Composite Energy Demand and Solar Energy Supply Curves for a 320-Acre Nebraska Farm. Includes Irrigation, Residence, Crop Drying and Animal Production 


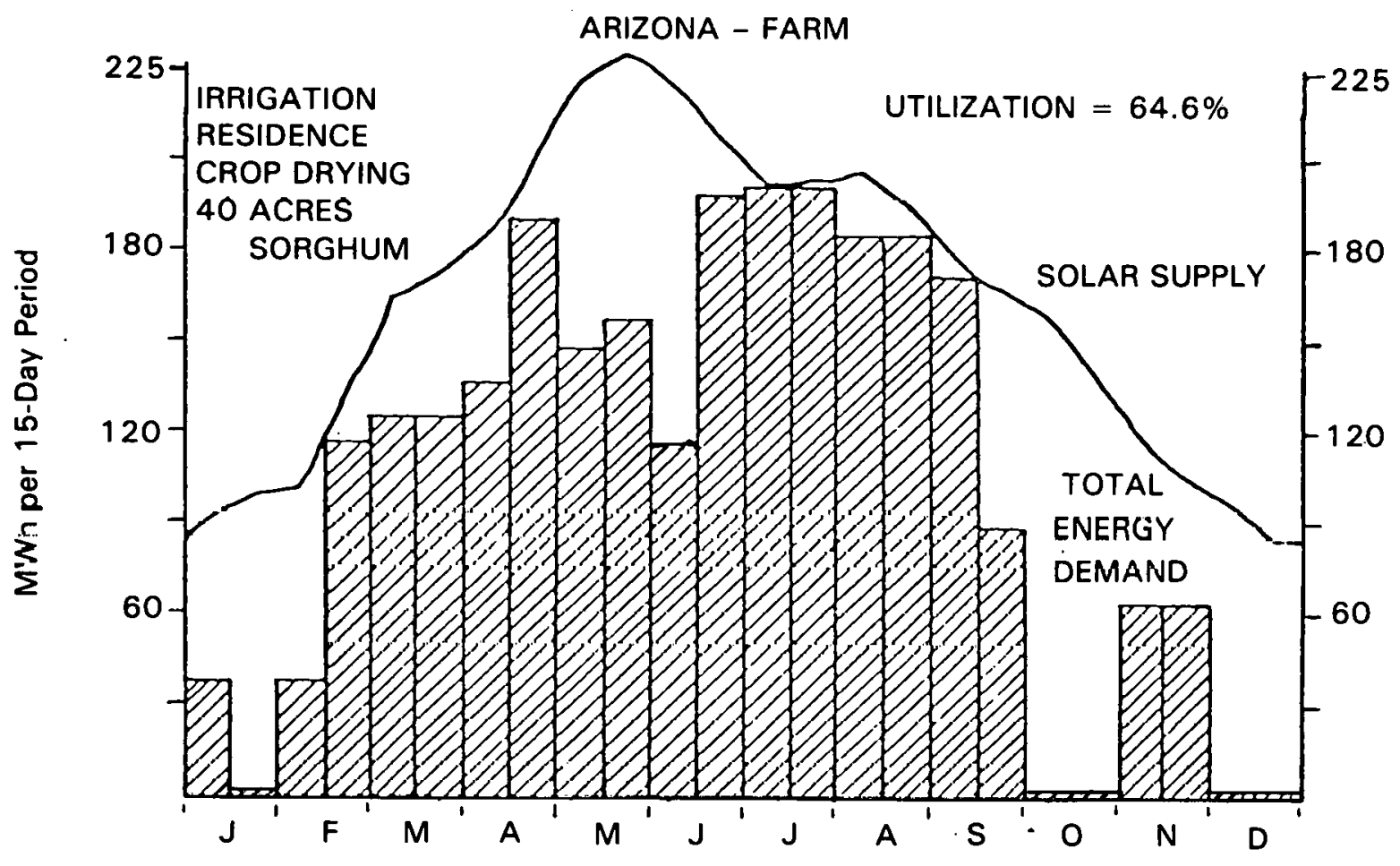

Figure A-5. Composite Energy Demand and Solar Energy Supply Curves for a 640-Acre Arizona Farm 


\title{
APPENDIX B
}

\author{
DERIVATION OF $K_{n}$ FOR VARIOUS REGIONS
}

Tables B- 1 through B- 6 were derived to aid in the calculations of the marginal utilization of each module added to a solar system. This allowed the calculation of the number of modules making up the optimally sized system, which led to the market size estimate.

(1) The annual power output of a module located on a farm in a given state was calculated as the product of the state's insolation level, the system efficiency, and the module size.

(2) The total solar energy supply for each state for a system designed to cover irrigation, crop, livestock operation and residential demands was taken from Reference 1. ("Supply" column of Tables B-1 to $B-6$. )

(3) Dividing the total annual solar thermal energy supply in $\mathrm{kWh} / \mathrm{yr}$. by the output of each module for a given state in $\mathrm{kWh} /$ module per year gives the equivalent number of $P D$ modules required for a farm in that state. (Number of Modules per Farm, Table B-1.)

(4) The contribution of each module in a given month was obtained by dividing the monthly solar thermal energy supply by the total number of installed modules from ( 3 ) above. ( $\bar{W}$ in the Tables.)

(5) Monthly demand was also obtained from Reference 6 .

(6) For each month, for each state, the number of modules needed to cover the total demand was calculated, as well as the energy contribution of the last module utilized, assuming all previous modules were fully utilized. The total number used in any month

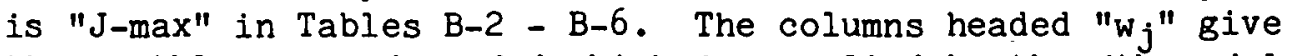
the monthly power demanded which is supplied by the jth module added to the system.

(7) The annual power used of that supplied by the jth module is the slum of the mont.hly simplies, and is the tint.al "wj".

(8) The total utilization of the jth module added to the system is in the row labeled $\mathrm{KJ}_{\mathrm{J}}$ and is the total power demand satisfied by the $j$ th module divided by the total annual supply per module.

(9) The utilization factor close to $\mathrm{K}_{\hat{N}}$, the optimal utilization of the nth module can now be read from the Tables for each state, for each type of fuel. The optimal number of modules per farm can be read from the table.

(10) The equivalent number of farms per state for each fuel type can be estimated by dividing the total energy demand for onfarm-pumped irrigation systems by fuel type and state (Ref. 6) by the total energy demand for the "typical" farm (Ref. 1). 
(11) The PD system market by state and fuel type was then estimated as the product of modules per farm (Item 9) and number of farms (Item 10).

It should be noted that, due to lack of data for Texas and Colorado, the representative farm supply and demand profiles for New Mexico were used to derive the utilization factor. 
Table B-1. Number of Modules per Farm per State

(Based on covering the peak demand)

No. Modules/Farm $=($ Solar Supply/Farm $) /\left(100 \mathrm{~m}^{2} /\right.$ module $\cdot 0.20$ system efficiency $\cdot$ insolation level $)$

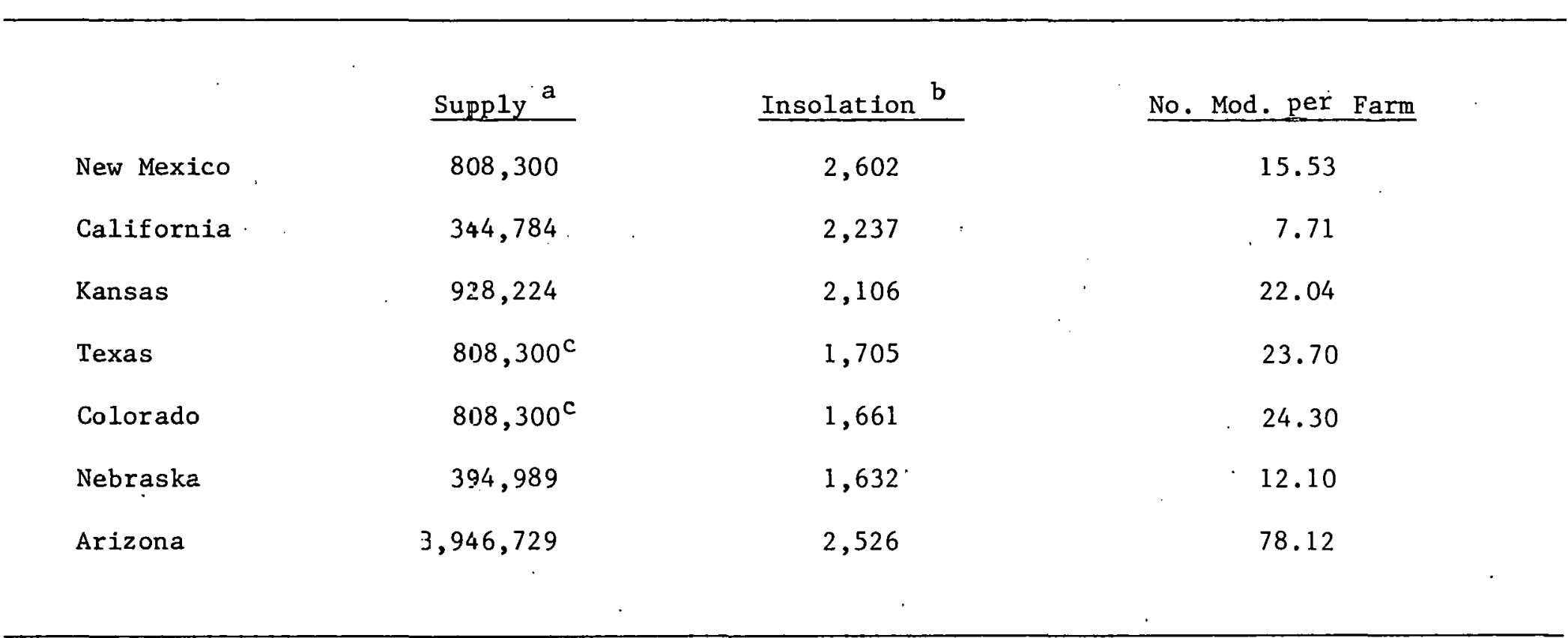

${ }^{a}$ Solar Supply for Total Demand (kWh), Ref. 1 .

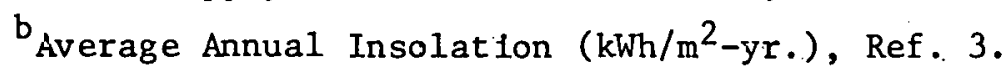

CHew Mexico's sollar supply data was used. 
Demand: Monthly totals are the totals of the two 15-day periols, total energy demanded, all farm uses. The representative farm of Reference 1 is used.

Supply: Total solar supply in $\mathrm{kWh}$ to cover all energy demands. Sum of two 15-day periods given in Reference 1 for the representative farm.

Number of Modules per Farm: from Table B-1.

$\overline{\mathrm{W}}$ : - Total supply per month divided by the number of installed nociules (kWh/modules).

J-Max.: Total number of modules needed by month to cover the nor:thly demand.

$\mathrm{w}_{j}$ : Marginal energy supplied by the $\mathrm{jth}$ module.

$\mathrm{K}_{\mathrm{j}}:\left(\right.$ Annual $\left.\mathrm{w}_{\mathrm{j}}\right) /($ Annual $\overline{\mathrm{W}})$. 
TABLE B-2

ARIZONA

\begin{tabular}{|c|c|c|c|c|c|c|c|c|c|c|c|c|c|}
\hline & DENAAND & SUPPLY & $\overline{\mathbf{W}}$ & J-Max. & $\mathrm{w}_{1}$ & $w_{2-15}$ & $w_{16}$ & $w_{17-42}$ & $w_{43}$ & $w_{44-49}$ & $w_{50}$ & $w_{50-52}$ & $w_{53}$ \\
\hline JAN. & 38,147 & 190,709 & 2,441 & 16 & 2,441 & 2,441 & 1,532 & - & - & - & - & - & - \\
\hline FEB. & $15 \epsilon, 328$ & 231,981 & 2,969 & 53 & 2,969 & 2,969 & 2,969 & 2,969 & 2,969 & 2,969 & 2,969 & 2,969 & 1,940 \\
\hline MAR. & 249,346 & 338,138 & 4,329 & 58 & 4,329 & 4,329 & 4,329 & 4,329 & 4,329 & 4,329 & 4,329 & 4,329 & 4,329 \\
\hline APR. & 326,419 & 394,938 & 5,055 & 65 & 5,055 & 5,055 & 5,055 & 5,055 & 5,055 & 5,055 & 5,055 & 5,055 & 5,055 \\
\hline MAY & 304,954 & 482,109 & $6,1 ? 1$ & 50 & 6,171 & 6,171 & 6,171 & 6,171 & 6,171 & 6,171 & 2,575 & - & - \\
\hline JUNE & 315,506 & 448,307 & 5,739 & 55 & 5,739 & 5,739 & 5,739 & 5,739 & 5,739 & 5,739 & 5,739 & 5,739 & 5,739 \\
\hline JULY & 398,536 & 400,295 & 5,124 & 78 & 5,124 & 5,124 & 5,124 & 5,124 & 5,124 & 5,124 & 5,124 & 5,124 & 5,124 \\
\hline AUG. & 372,296 & 402,054 & 5,146 & 73 & 5,146 & 5,146 & 5,146 & 5,146 & 5,146 & 5,146 & 5,146 & 5,146 & 5,146 \\
\hline SEPT. & 262,706 & 345,659 & 4,425 & 60 & 4,425 & 4,425 & 4,425 & 4,425 & 4,425 & 4,425 & 4,425 & 4,425 & 4,425 \\
\hline OCT. & 1.734 & 299,583 & 3,835 & 1 & 1,734 & - & - & - & - & - & - & - & - \\
\hline Nov. & 124,036 & 226,111 & 2,894 & 43 & 2,894 & 2,894 & 2,894 & 2,894 & 2,488 & - & - & - & - \\
\hline DEC. & 1,036 & 186,795 & 2,391 & 1 & 1,036 & - & - & - & - & - & - & - & - \\
\hline TOTAL & $2,551,044$ & $3,946,729$ & 50,519 & - & 47,063 & 44,293 & 43,384 & 41,852 & 41,446 & 38,958 & 35,362 & 32,787 & 31,758 \\
\hline$k_{j}$ & - & - & - & - & 0.93 & 0.88 & 0.86 & 0.83 & 0.82 & 0.77 & 0.70 & 0.65 & 0.63 \\
\hline
\end{tabular}

No. Installed Moduies $=78,12$ Reference 1, p. 24 
TABLE B-2 (Cont'd)

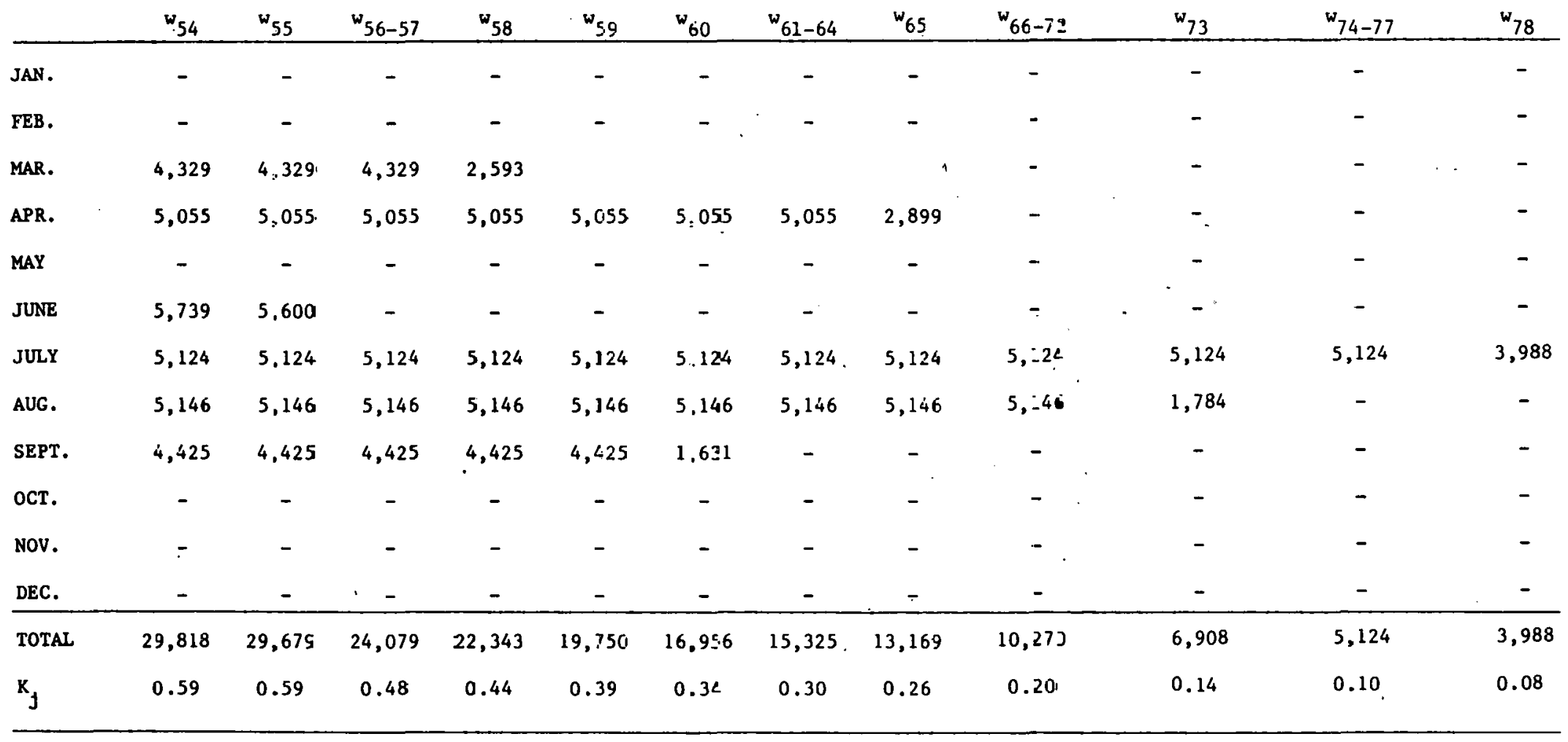

No. Installed Modules $=7 \varepsilon .12$.

Reference 1, p. 24. 
TABLE B-3

CALIFORNIA

\begin{tabular}{|c|c|c|c|c|c|c|c|c|c|c|c|}
\hline & DEMAND & SUPPLY & $\overline{\mathbf{W}}$ & J-Max. & $w_{1}$ & $w_{2}$ & $w_{3}$ & $w_{4}$ & $w_{5}$ & ${ }_{6} 6$ & $w_{7}$ \\
\hline JAN. & 1,816 & $7,5=1$ & 975 & 2 & 975 & 841 & - & - & - & - & - \\
\hline FEB. & 1,600 & $13,1 \equiv 2$ & 1,703 & 1 & 1,600 & - & - & - & - & - & - \\
\hline MAR. & 1,268 & $27,0 \leq 7$ & 3,509 & 1 & 1,268 & - & - & - & - & - & - \\
\hline APR. & 17,238 & $33,9 \leq 7$ & 4,404 & 4 & 4,404 & $4,404^{\circ}$ & 4,404 & 4,026 & - & - & - \\
\hline MAY & 33,342 & $41,06.7$ & 5,326 & 7 & 5,326 & 5,326 & 5,326 & 5,326 & 5,326 & 5,326 & 1,386 \\
\hline JUNE & 17,134 & $45,7 \subseteq 9$ & 5,940 & 3 & 5,940 & 5,940 & 5,254 & - & - & - & - \\
\hline JULY & 33,488 & $47,4 \varepsilon, 9$ & 6,159 & 6 & 6,159 & 6,159 & 6,159 & 6,159 & 6,159 & 2,693 & - \\
\hline AUG. & 17,298 & 43,6012 & 5,655 & 4 & 5,655 & 5,655 & 5,655 & 333 & - & - & - \\
\hline SEPT. & 1,050 & $36,1 \in .6$ & 4,691 & 1 & 1,050 & - & - & - & - & - & - \\
\hline OCT. & 808 & $26,8 \equiv 8$ & 3,481 & 1 & 808 & - & - & - & - & - & - \\
\hline Nov. & 988 & $14,5 \equiv 4$ & 1,885 & 1 & 988 & - & - & - & - & - & - \\
\hline DEC. & 1,344 & $7,6 \div 2$ & 989 & 2 & 989 & 355 & - & - & - & - & - \\
\hline TOTAL. & 127,374 & $344,7 \varepsilon 4$ & 44,717 & - & 35,162 & 28,680 & 26,798 & 15,844 & 11,485 & 8,019 & 1,386 \\
\hline $\mathrm{K}_{\mathrm{j}}$ & - & - & - & - & 0.79 & 0.64 & 0.60 & 0.35 & 0.26 & 0.18 & 0.03 \\
\hline
\end{tabular}

No. Installed Modules $=7.71$.

Reference 1, p. 28. 
TABLE B-4

KANSAS

\begin{tabular}{|c|c|c|c|c|c|c|c|c|c|c|}
\hline & DEMAND & SUPPLY & $\overline{\mathrm{W}}$ & J-Max. & $w_{1-3}$ & $w_{4}$ & $w_{5}$ & $w_{5}$ & $w_{7}$ & $\mathrm{w}_{8}$ \\
\hline JAN. & 9,554 & 44,656 & 2,026 & 5 & 2,026 & 2,026 & 1,450 & - & - & - \\
\hline FEB. & 8,848 & 56,474 & 2,562 & 4 & 2,562 & 1,162 & - & - & - & - \\
\hline MAR. & 49,592 & 68,292 & 3,099 & 17 & 3,099 & 3,099 & 3,099 & 3,099 & 3,399 & 3,099 \\
\hline APR. & 34,460 & 87,050 & 3,950 & 9 & 3,950 & 3,950 & 3,950 & 3,950 & 3,350 & 3,950 \\
\hline MAY & 47,612 & 90,117 & 4,089 & 12 & 4,089 & 4,089 & 4,089 & 14,089 & 4,389 & 4,089 \\
\hline JUNE & 54,596 & 107,618 & 4,883 & 12 & 4,883 & 4,883 & 4,883 & 4,833 & 4,383 & 4,883 \\
\hline JULY & 116,670 & 117,173 & 5,316 & 22 & 5,316 & 5,316 & 5,316 & 5,316 & 5,316 & 5,316 \\
\hline AUG. & 100,692 & 109,127 & 4,951 & 21 & 4,951 & 4,951 & 4,951 & 4,951 & 4,751 & 4,951 \\
\hline SEPT. & 41,714 & 86,240 & 3,913 & 11 & 3,913 & 3,913 & 3,913 & 3,913 & 3,313 & 3,913 \\
\hline oct. & 26,836 & 74,327 & 3,372 & 8 & 3,372 & 3,372 & 3,372 & 3,372 & 3,372 & 3,232 \\
\hline Nov. & 11,984 & 50,691 & 2,300 & 6 & 2,300 & 2,300 & 2,300 & 434 & - & - \\
\hline DEC. & 9.142 & 36.459 & 1,654 & 6 & 1.654 & 1.654 & 1,654 & 872 & - & - \\
\hline TOTAL. & 511,700 & 928,224 & 42,115 & - & 42,115 & 40,715 & 38,977 & 34,929 & 35,573 & 33,433 \\
\hline$k_{j}$ & -1 & - & - & - & 1.0 & 0.97 & 0.93 & 0.83 & 0.30 & $0.79^{\circ}$ \\
\hline
\end{tabular}

No. Installed Modules $=22.04$

Reference 1, p. 35. 
TABLE B-4 (Cont'd)

\begin{tabular}{|c|c|c|c|c|c|c|c|c|c|}
\hline & $w_{9}$ & ${ }^{w_{10}}$ & $w_{11}$ & $w_{12}$ & w $13-16$ & $w_{17}$ & $w_{18-20}$ & $w_{21}$ & $w_{22}$ \\
\hline JAN. & - & - & - & - & - & - & - & - & - \\
\hline FEB. & - & - & - & - & - & - & - & - & - \\
\hline MAR. & 3,099 & 3,099 & 3,099 & 3,099 & 3,099 & 8 & - & - & - \\
\hline APR. & 2,860 & - & - & - & - & - & - & - & - \\
\hline MAY & 4,089 & 4,089 & 4,089 & 2,633 & - & - & - & - & - \\
\hline JUNE & 4,883 & 4,883 & 4,883 & 833 & - & - & - & - & - \\
\hline JULY & 5,316 & 5,316 & 5,316 & 5,316 & 5,316 & 5,316 & 5,316 & 5,316 & 5,034 \\
\hline AUG. & 4,951 & 4,951 & 4,951 & 4,951 & 4,951 & 4,951 & 4,951 & 1,672 & - \\
\hline SEPT. & 3,913 & 3,913 & 2,584 & - & - & - & . - & - & - \\
\hline ○ст. & - & - & - & - & - & - & - & - & - \\
\hline Nov. & - & - & - & - & - & - & - & - & - \\
\hline DEC. & - & - & - & - & - & $=$ & $=$ & - & - \\
\hline TOTAL & 29,111 & 26,251 & 24,922 & 16,882 & 13,366 & 10,275 & 10,267 & 6,988 & 5,034 \\
\hline$K_{j}$ & 0.69 & 0.62 & 0.59 & 0.40 & 0.32 & 0.24 & 0.24 & 0.17 & 0.12 \\
\hline
\end{tabular}

No. Installed Modules $=22.04$. Reference $1, p .35$. 
TABLE B-5

NEBRASKA

\begin{tabular}{|c|c|c|c|c|c|c|c|c|c|c|c|c|c|c|c|}
\hline & DEMAND & SUPPLY & $\overline{\mathrm{W}}$ & $\mathrm{J}$ Ma: & $w_{1}$ & $w_{\tau}$ & $w_{3}$ & $w_{4}$ & $w_{5}$ & $w_{6}$ & $w_{7}$ & $w_{8}$ & $w_{9}$ & $w_{10-11}$ & ${ }^{k} 12$ \\
\hline JAN. & 5,944 & 19,003 & 1,571 & 4 & 1,571 & 1,571 & 1,571 & 1,231 & - & - & - & - & - & - & - \\
\hline FEB. & 5,462 & 24,032 & 1,986 & 3 & 1,986 & $1, \subseteq 86$ & 1,490 & - & - & - & - & - & - & - & - \\
\hline MAR. & 5,074 & 29,061 & 2,402 & 3 & 2,402 & $2, \angle 02$ & 270 & - & - & - & - & - & - & - & - \\
\hline APR. & 4,116 & 37,043 & 3,061 & 2 & 3,061 & 1,0155 & - & - & $\therefore$ & - & - & - & - & - & - \\
\hline MAY & 3,728 & 38,349 & 3,169 & 2 & 3,169 & 5.59 & - & - & - & - & - & - & - & - & - \\
\hline JUNE & 33,390 & 45,796 & 3,785 & 9 & 3,785 & $3,-85$ & 3,785 & 3,785 & 3,785 & 3,785 & 3,785 & 3,785 & 3,110 & - & - \\
\hline JULY & 33,470 & 50,132 & 4,143 & 9 & 4,143 & 4,143 & 4,143 & 4,143 & 4,143 & 4,143 & 4,143 & 4,143 & 326 & - & - \\
\hline AUG. & 43,592 & 46,406 & 3,835 & 12 & 3,835 & 3,835 & 3,835 & 3,835 & 3,835 & $3: 835$ & 3,835 & 3,835 & 3,835 & 3,835 & 1,407 \\
\hline SEPT. & 3,818 & 36,722 & 3,035 & 2 & 3,035 & $: 83$ & - & - & - & - & - & - & - & - & - \\
\hline OCT. & 18,236 & 31,629 & 2,614 & 7 & 2,614 & 2,614 & 2,614 & 2,614 & 2,614 & 2,614 & 2,552 & - & - & - & - \\
\hline DEC. & 5.660 & 15,515 & 1,282 & 5 & 1,282 & 1,282 & 1,282 & 1,282 & 532 & - & - & - & - & - & - \\
\hline TOTAL & 173,516 & 394,989 & 32,666 & - & 32,666 & $25,: 98$ & 20,773 & 18,673 & 16,692 & 16,160 & 14,643 & 11,763 & 7,271 & 3,835 & 1,407 \\
\hline$k_{j}$ & - & - & - & - & 1.00 & 0.79 & 0.64 & 0.57 & 0.51 & 0.49 & 0.45 & 0.36 & 0.22 & 0.12 & 0.04 \\
\hline
\end{tabular}


TABंLE B-6

NEW MEXICO

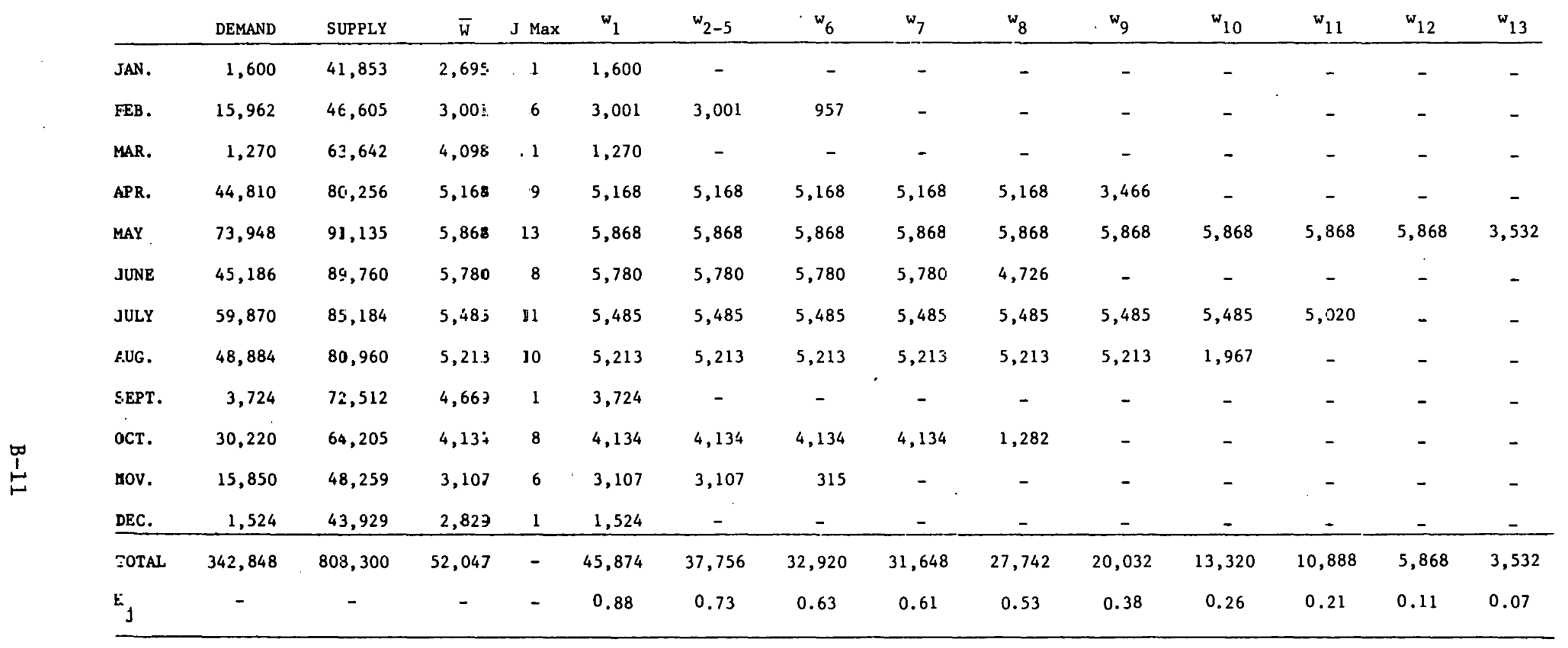

No. Installed Modules $=15.53$.

Reference 1, p. 43. 